\title{
Enzymatic Alterations in Litopenaeus vannamei (Boone, 1931) Juveniles Exposed to Different Levels of Dietary Potassium and Magnesium Reared in Inland Saline Water
}

\author{
Iffat Jahan, Showkat Ahmad Dar, Garima Anand, Shashank Singh, \\ A.K. Reddy*, Arun Sudhagar, V. Harikrishna and P.P. Srivastava \\ ICAR- Central Institute of Fisheries Education, Mumbai- 400 061, India \\ *Corresponding author
}

A B S T R A C T

Inland saline water (ISW) are deficient in potassium with high levels of calcium and variable concentrations of magnesium, large steps were taken to balance these essential ions using commercial fertilizers for growth of Litopenaeus vannamei. Since these

Keywords

Inland saline water,

Magnesium ions,

Potassium ions,

Litopenaeus

vannamei, Enzymes.

Article Info

Accepted:

10 September 2017

Available Online:

10 November 2017 methods needs large quantities of fertilizers and involves high cost, the present study was made to explore the use desired mineral supplements through feed rather than in water. A 60 days trial was conducted to investigate the effect of different dietary levels of $\mathrm{K}^{+}, \mathrm{Mg}^{2+}$ on L. vannamei juveniles in two types of water namely raw (R-ISW) and $100 \% \mathrm{~K}^{+}-\mathrm{Mg}^{2+}$ fortified water (F-ISW) as sea water at constant salinity $10 \mathrm{ppt}$. Three gelatin coated diet were formulated with varied $\mathrm{K}^{+}$and $\mathrm{Mg}^{2+}$ levels $\left(\mathrm{K}^{+}=5 \mathrm{~g} / \mathrm{kg}, \mathrm{Mg}^{2+}=150 \mathrm{mg} / \mathrm{kg}, \mathrm{K}^{+}=10\right.$ $\mathrm{g} / \mathrm{kg}, \mathrm{Mg}^{2+}=300 \mathrm{mg} / \mathrm{kg}, \mathrm{K}^{+}=15 \mathrm{~g} / \mathrm{kg}, \mathrm{Mg}^{2+}=450 \mathrm{mg} / \mathrm{kg}$ ) and commercial shrimp feed serves as basal diet. There is a significant difference in enzymatic activity in all treatments regarding with or without supplemented feed in F-ISW and R-ISW. Enzymatic activity of hemolymph parameters, SOD, Catalase, AST, ALT and total haemocyte counts were significant different $(\mathrm{P}<0.05)$ in both F-ISW with dietary minerals ions alteration and in FISW without supplemented feed as compared to other treatments. There was a significant $(\mathrm{P}<0.05)$ higher difference in digestive enzymes in F-ISW compared to other treatments. The present study indicates that there is stress for treatments where lack of dietary mineral ions in ISW compared to F-ISW.

\section{Introduction}

The demand for aquaculture has increased which led to the development of new production systems. Inland saline aquaculture is one of the newly emerging areas of aquaculture research and has been developing throughout the world. Inland saline aquaculture is defined as the land-based aquaculture using saline ground water, occurs in several countries including Australia, China, Egypt, Iraq, Mexico, USA, Pakistan, Turkey, and India. Salinization is caused due to water logging, poor drainage, indiscriminate use of inorganic fertilizers, non-utilization of ground saline water and various anthropogenic causes. The gradual increase of ground water levels with time causing secondary salinization and water logging with poor water quality.

In India, around 6.75 million ha of agricultural land has been badly affected by the problem of soil salinity (Mandal et al., 
2010). The states viz. Haryana, Uttar Pradesh, Punjab, and Rajasthan contribute about $40 \%$ to these salt affected lands in the country. To resolve this problem, the inland saline aquaculture has been identified as the most suitable and potential option because it involves culture of various species of marine, euryhaline, diadromous or freshwater-salt tolerant species in ground saline water from inland locations. The quality of Inland saline water is quite different than natural seawater, mainly in ionic composition. Potassium concentration is very low as compared to natural sea water at different salinities. Similarly, high levels of calcium and variables levels of magnesium in Inland saline water (ISW) (Lakra et al., 2014).

To enhance the growth, survival, and production of shrimp reared in Inland saline water two different strategies have been employed by farmers and researchers. These strategies include water modification approaches which alter the low saline rearing medium as similar as sea water to make it more acceptable for the production of shrimp and nutritional strategies include dietary modification, usually with the supplementation of essential minerals that might provide an osmoregulatory advantage in ISW (Roy and Davis, 2010).

A variety of aquatic species have been reared in Inland saline water around the world (Rahman et al., 2005). The inland culture of shrimp, predominantly the Pacific white shrimp is becoming more widespread in the Western hemisphere, which is native to the Pacific coast from Northern Peru to Mexico. L. vannamei is mainly found on mud bottoms of sea, down to a depth of $75 \mathrm{~m}$. It is an omnivorous scavenger and is less aggressive and less carnivorous than $P$. monodon. Growth of $L$. vannamei, under confined culture conditions was similar to $P$. monodon till they attain $20 \mathrm{~g}$ size. Beyond that growth rate is poor. The shrimp attains the size of $20 \mathrm{~g}$ within a period of 100-120 days depending on stocking density (Lakra et al., 2014).

\section{Materials and Methods}

The present study was carried out on $L$. vannamei (Boone, 1931) fed with different dietary potassium and magnesium levels to assess the enzymatic performance between raw Inland saline water (R-ISW) with fortified feed and supplemented mineral ions both in water feed (F-ISW).

The experiments have been carried out for a period of 60 days at ICAR-CIFE, Rohtak, Haryana, India. The specific pathogen free (SPF) L. vannamei (PL15) seeds were procured from Geekay Hatcheries, Nellore, Andhra Pradesh, India to the experimental site. Reared in earthen ponds for a period of 30 days at 10 ppt salinity to obtain juveniles $(3.19 \pm 0.18 \mathrm{~g})$ for the experiment.

The juvenile shrimps were collected from the pond, acclimatized and nursed FRP tanks for a period of 6 days with sufficient aeration and ad libitum feeding.

The experiment consisted of three treatments with three different dietary potassium and magnesium levels by gelatin coating and a control. ISW with commercial shrimp feed (F4 feed) was used as control group (C), $\mathrm{K}^{+}-$ $\mathrm{Mg}^{2+}$ fortified water $(\mathrm{FW})$ with commercial shrimp feed was used as treatment T1, ISW with three different fortified feeds (FF) at $\mathrm{K}^{+}$ $=5 \mathrm{~g} / \mathrm{kg}, \mathrm{Mg}^{2+}=150 \mathrm{mg} / \mathrm{kg}$ feed $(\mathrm{F} 1$ feed $), \mathrm{K}^{+}$ $=10 \mathrm{~g} / \mathrm{kg}, \mathrm{Mg}^{2+}=300 \mathrm{mg} / \mathrm{kg}$ feed $(\mathrm{F} 2$ feed $)$ and $\mathrm{K}^{+}=15 \mathrm{~g} / \mathrm{kg}, \mathrm{Mg}^{2+}=450 \mathrm{mg} / \mathrm{kg}$ feed $(\mathrm{F} 3$ feed) were used as treatment $\mathrm{T} 2, \mathrm{~T} 3$ and $\mathrm{T} 4$ respectively, and FW with $\mathrm{FF}$ ) at $\mathrm{K}^{+}=5 \mathrm{~g} / \mathrm{kg}$, $\mathrm{Mg}^{2+}=150 \mathrm{mg} / \mathrm{kg}$ feed, $\mathrm{K}^{+}=10 \mathrm{~g} / \mathrm{kg}, \mathrm{Mg}^{2+}=$ $300 \mathrm{mg} / \mathrm{kg}$ feed and $\mathrm{K}^{+}=15 \mathrm{~g} / \mathrm{kg}, \mathrm{Mg}^{2+}=450$ $\mathrm{mg} / \mathrm{kg}$ feed were used as treatment $\mathrm{T} 5, \mathrm{~T} 6$ and T7 respectively. 
$5 \%$ homogenate extracts of muscle, hepatopancreas, intestine and gill extracts were prepared in $0.25 \mathrm{M}$ sucrose solution. Quantification of protein of the different tissues was carried out by using Bradford method (Bradford, 1976). Haemolymph protein was determined by biuret method (Reinhold, 1953).

Albumin was estimated by Bromocresol green binding method (Doumas et al., 1971). Globulin was calculated by subtracting albumin values from total haemolymph protein and $\mathrm{A} / \mathrm{G}$ ratio calculated by dividing albumin values by globulin values.

Total haemocyte count (THC) was performed immediately at the end of experiment by a Neubauer haemocytometer with a drop of anticoagulant haemolymph. THC was done by counting the haemocytes under an Olympus light microscope and expressed as cells $\mathrm{ml}^{-1}$ haemolymph.

Number of haemocytes $/ \mathrm{ml}=\frac{\text { N x Dilution }}{\text { Globulin in }(\mathrm{g} / \mathrm{dl})}$

Where, N: Numbers of haemocytes counted

Superoxide dismutase (SOD) was assayed according to the method described by Misra and Fridovich (1972) based on the oxidation of epinepherine-adrenochrome transition by the enzyme. Catalase (CAT) was estimated based on the methodology of Takahara et al., (1960).

Aspartate aminotransferase (AST) and Alanine aminotransferase (ALT) activity were assayed in different tissue homogenates as described by Wooten (1964). Digestive enzymes such as amylase [by Dinitro-salicylic acid (DNS) method] and protease were also estimated (Rick and Stegbauer, 1974).

\section{Results and Discussion}

It is significant to note that, all the animals died within 3 days from the start of the experiment in control group (C), were the animals reared in R-ISW by using $\mathrm{F} 4$ feed which had no potassium and magnesium supplementation. Therefore control group has been excluded from this study. The haemolymph protein and albumin given in Table 1 were significantly higher $(P<0.05)$ for T6, T5, T7 and T1 compared to other treatments. The highest serum globulin (Table 1) was significantly higher $(P<0.05)$ for $\mathrm{T} 1$, T5, T7, and T6 treatment. The lowest A: G ratio was observed in the $\mathrm{T} 4$ treatments. The total haemocyte counts of different treatments (Table 1$)$ significantly higher $(P<0.05)$ for T6 followed by $\mathrm{T} 1, \mathrm{~T} 7$ and lowest in $\mathrm{T} 2$ treatments.

Superoxide dismutase, Catalase activity, AST and ALT value in hepatopancrease of different treatments are given in Table 2, was significant difference $(\mathrm{p}<0.05)$ between all treatments for F-ISW having supplementation of mineral ions in both feed and water and among R-ISW treatment groups where no supplementation of potassium and magnesium in water. Protease and Amylase activity in the digestive tract were analyzed for all the treatments (Table 2), was significantly $(\mathrm{P}<0.05)$ higher in T6 treatments. Results clearly indicates, stress among the treatment where diet having absence of potassium and magnesium supplementation.

Currently rearing of shrimp using Inland saline water (ISW) presents a good opportunity to expand the culture of marine species other than the coastal areas (Roy et $a l ., 2009)$. In ISW as the production of shrimp continues to expand so there is a need to do cost effective methods for increasing the availability of necessary ions to the organism in order to ensure proper survival and growth. 
As the application of agricultural fertilizers containing sources of $\mathrm{K}^{+}$and $\mathrm{Mg}^{2+}$ directly to the pond water of ISW have been reported effective method for improving growth and survival but the method of dietary potassium magnesium fortification may either allow reductions in the levels of supplements added to the water or provided additional performance in these ISW (Roy, 2006).

Riche (2007) stated that health condition, stress status and body condition of aquatic species can be measured using total haemolymph protein as a clinical indicator. Because, serum protein helps in ionic regulation and transport of the molecules which acts as a pathological defense agents (Rudneva and Kowrshina, 2011).

Young chum salmon (Oncorhychus keta) exposed to various salinities showed lower serum total protein, albumin and globulin content (Liu et al., 2013). Among the haemolymph proteins, albumin and globulin are major proteins which play an important role in the immune response. The haemolymph globulins consist of several components like alpha beta and gamma. The gamma globulin fraction is the source of the all immune proteins in the blood.

Changes in the levels of haemolymph components have been described earlier in shrimps, under several physiological conditions such as changes in protein composition in some penaeids related to sex and animal size (Chen and Cheng, 1993), environmental ammonia- $\mathrm{N}$ (Chen and Cheng, 1995; and water salinity (Chen et al., 1994). Present study indicated that these must be particularly stressful to the shrimps and that haemolymph protein parameters level can potentially function as a stress indicator to monitor shrimp health status. Similarly Perazzolo et al., (2002) reported that reduction of in the haemolymph protein concentration of stressed shrimps is mostly due to deficiencies of mineral ions in the raw ISW, so that shrimps were not able to osmoregulate, resulting shrimp stressed, reduced growth, and even mortality but possibly also to specific immune proteins.

Table.1 Haemolymph protein parameters and total haemocyte count of $L$. vannamei in different treatment groups. Means \pm standard error $(n=3)$, followed by different superscripts indicates significant differences between treatments $(\mathrm{p}<0.05)$

\begin{tabular}{cccccc}
\hline Treatments & $\begin{array}{c}\text { Haemolymph } \\
\text { Protein }(\mathbf{g} / \mathbf{d l})\end{array}$ & Albumin $(\mathbf{g} / \mathbf{d l})$ & $\begin{array}{c}\text { Globulin } \\
(\mathbf{g} / \mathbf{d l})\end{array}$ & A/G & THC $\left(\mathbf{1}^{*} \mathbf{1 0}^{\mathbf{6}} / \mathbf{m l}\right)$ \\
\hline T1 & $11.64^{\mathrm{d}} \pm 0.15$ & $3.02^{\mathrm{e}} \pm 0.21$ & $8.62^{\mathrm{d}} \pm 0.25$ & $0.35^{\mathrm{b}} \pm 0.01$ & $5.45^{\mathrm{e}} \pm 0.02$ \\
T2 & $9.83^{\mathrm{b}} \pm 0.19$ & $2.29^{\mathrm{c}} \pm 0.22$ & $7.53^{\mathrm{a}} \pm 0.28$ & $0.30^{\mathrm{a}} \pm 0.01$ & $2.54^{\mathrm{a}} \pm 0.03$ \\
T3 & $10.15^{\mathrm{c}} \pm 0.24$ & $2.60^{\mathrm{d}} \pm 0.23$ & $7.55^{\mathrm{a}} \pm 0.23$ & $0.34^{\mathrm{b}} \pm 0.01$ & $2.63^{\mathrm{a}} \pm 0.05$ \\
T4 & $9.51^{\mathrm{a}} \pm 0.27$ & $1.94^{\mathrm{a}} \pm 0.23$ & $7.56^{\mathrm{a}} \pm 0.25$ & $0.25^{\mathrm{a}} \pm 0.02$ & $2.92^{\mathrm{b}} \pm 0.03$ \\
T5 & $11.92^{\mathrm{e}} \pm 0.28$ & $3.7^{\mathrm{a}} \pm 0.28$ & $8.45^{\mathrm{b}} \pm 0.22$ & $0.41^{\mathrm{d}} \pm 0.02$ & $4.76^{\mathrm{c}} \pm 0.03$ \\
T6 & $12.15^{\mathrm{f}} \pm 0.29$ & $3.76^{\mathrm{h}} \pm 0.21$ & $8.38^{\mathrm{b}} \pm 0.27$ & $0.44^{\mathrm{e}} \pm 0.01$ & $7.36^{\mathrm{f}} \pm 0.02$ \\
T7 & $11.71^{\mathrm{d}} \pm 0.29$ & $3.27^{\mathrm{f}} \pm 0.23$ & $8.44^{\mathrm{b}} \pm 0.27$ & $0.38^{\mathrm{c}} \pm 0.01$ & $5.15^{\mathrm{e}} \pm 0.01$ \\
\hline
\end{tabular}


Table.2 SOD, CAT, AST, ALT, Protease and Amylase activity of L. vannamei in different treatments groups; means \pm standard error $(n=3)$, followed by different superscripts indicates significant differences control and treatments $(\mathrm{p}<0.05)$

\begin{tabular}{lllllll}
\hline Treatments & SOD & Catalase & AST activity & ALT activity & Protease & Amylase \\
\hline T1 & $1.75^{\mathrm{a}} \pm 0.03$ & $1.26^{\mathrm{a}} \pm 0.01$ & $110.96^{\mathrm{b}} \pm 3.10$ & $60.08^{\mathrm{ab}} \pm 2.17^{\mathrm{b}}$ & $1.14^{\mathrm{d}} \pm 0.05$ & $0.1^{\mathrm{e}} \pm 0.002$ \\
T2 & $2.21^{\mathrm{c}} \pm 0.05$ & $2.18^{\mathrm{c}} \pm 0.03$ & $121.9^{\mathrm{b}} \pm 2.22$ & $66.14^{\mathrm{b}} \pm 2.37$ & $0.95^{\mathrm{b}} \pm 0.01$ & $0.07^{\mathrm{b}} \pm 0.003$ \\
T3 & $2.01^{\mathrm{c}} \pm 0.03$ & $2.06^{\mathrm{c}} \pm 0.04$ & $121.16^{\mathrm{b}} \pm 2.18$ & $58.87^{\mathrm{a}} \pm 2.63$ & $1.04^{\mathrm{c}} \pm 0.01$ & $0.07^{\mathrm{d}} \pm 0.002$ \\
T4 & $2.24^{\mathrm{c}} \pm 0.05$ & $2.17^{\mathrm{c}} \pm 0.01$ & $116.33^{\mathrm{b}} \pm 5.71$ & $58.87^{\mathrm{ab}} \pm 4.48$ & $1.0^{\mathrm{c}^{\mathrm{c}} \pm 0.02}$ & $0.07^{\mathrm{c}} \pm 0.003$ \\
T5 & $1.69^{\mathrm{a}} \pm 0.04$ & $1.16^{\mathrm{a}} \pm 0.01$ & $94.3^{\mathrm{a}} \pm 4.33$ & $58.87^{\mathrm{a}} \pm 4.41$ & $1.14^{\mathrm{d}} \pm 0.01$ & $0.11^{\mathrm{f}} \pm 0.002$ \\
T6 & $1.65^{\mathrm{a}} \pm 0.05$ & $1.36^{\mathrm{b}} \pm 0.01$ & $87.59^{\mathrm{a}} \pm 2.96$ & $58.87^{\mathrm{a}} \pm 1.37$ & $1.22^{\mathrm{e}} \pm 0.001$ & $0.13^{\mathrm{g}} \pm 0.002$ \\
T7 & $1.81^{\mathrm{a}} \pm 0.03$ & $1.32^{\mathrm{a}} \pm 0.06$ & $92.06^{\mathrm{a}} \pm 2.08$ & $58.87^{\mathrm{ab}} \pm 4.08$ & $1.11^{\mathrm{d}} \pm 0.03$ & $0.1^{\mathrm{e}} \pm 0.002$ \\
\hline
\end{tabular}

It was recently shown that shrimp haemocytes, besides their role in cellular immune reactions, are the principal site of expression of genes encoding immune effectors (Gross et al., 2001). Therefore, a prolonged decrease in THC in cultivated shrimps exposed to some physiological or environmental stress. A decrease in THC is frequently reported in marine crustaceans exposed to certain stress conditions. Sanchez et al., (2001) described that the THC of male L. setiferus maintained in captivity for 7 days at $270 \mathrm{C}$ decreased by $43 \%$ in comparison to freshly caught shrimps. Similarly the THC of $P$. japonicus declined after experimental viral infection (Hennig et al., 1998) or after being fed with a commercial diet containing peptidoglycans. Few authors suggested that the THC reduction was probably due to the increase in haemolymph volume rather than to a real decrease in cell numbers same as in the present study result has shown that higher value of THC in T6 followed by T1, T7 and lowest in $\mathrm{T} 2$, followed by $\mathrm{T} 3$ and $\mathrm{T} 4$ treatment groups.

Oxidative stress results when the antioxidant defenses are overcome by prooxidant forces and reactive oxygen species are not removed adequately (Sies et al., 1992). Living organisms are protected from the ROS by several defense mechanisms, including antioxidant enzymes such as SOD and Catalase. Superoxide dismutase (SOD is defined for scavenging superoxide radicals, is involved in defensive mechanisms within tissue injury for oxidative process and phagocytosis. The higher value of SOD indicates the more superoxide radicals need to be reacted. SOD activity depends on nutrient requirements, health enhancement, pollution stress monitoring, pesticide effects, disease indication, thermal or osmotic stress and other environmental factors. Basically, increase in SOD and Catalase indicates there are more radicals need to be reacted (Chien et al., 2003). Therefore significant higher SOD and Catalase activity were found in R-ISW treatments where shrimp reared in ISW which was deficient in mineral ions leads to create problem in ion regulation and osmoregulation mechanism.

In the present study, the AST and ALT activity was studied in the hepatopancreas, result has shown that the mean AST and ALT value in R-ISW treatments was higher than FISW treatments as similar to the finding of Mohankumar and Ramasamy (2006) in Fenneropenaeus indicus but there were no significance difference $(\mathrm{p}<0.05)$ among the treatment groups. Several aminotransferases 
in different tissues and organs including the hepatopancreas of crustaceans have been studied, including AST and ALT in lobster Homarus americanus (Devereaux, 1986), kynurenine aminotransferase in tiger prawn (Meunpol et al., 1998), and D-alanine oxidase and D-aspartate oxidase in several crustacean species (D’Aniello and Giuditta, 1980).

The digestive enzyme activity helps in understanding the digestive physiology and nutritional requirements of White shrimp. In crustaceans, digestive enzymes play an important role in nutritional physiology, growth regulation (Van Wormhouldt 1973) and dietary formulation (Le Moullac et al., 1994, 1996). In the present study result has shown that Amylase and protease activity in hepatopancreas was significantly $(\mathrm{P}<0.05)$ higher in T6 treatments similar to the finding of Li et al., 2008 in L. vannamei.

The present study indicated that dietary mineral ions supplementation are beneficial for better growth performance to shrimp rather than directly adding into water. This method will be cost effective and economical for farmers.

\section{References}

Bradford, M. M., 1976. A rapid and sensitive method for the quantitation of microgram quantities of protein utilizing the principle of protein-dye binding. Analytical Biochemistry, 72: 248-254

Chanson, M. and Spray, D.C., 1992. Gating and single channel properties of gap junction channels in hepatopancreatic cells of Procambarus clarkii. Biological Bulletin of the Marine Biological Laboratory, Woods Hole, Mass. Boston, MA, 183:341-342

Chen, J. C. and Cheng, S. Y., 1993. Studies in hemocyanin and hemolymph protein levels of Penaeus japonicus based on sex, size and moulting cycle. Comparative Biochemistry and Physiology Part C: Toxicology and Pharmacology, 106B: 293-296.

Chen, J. C. and Cheng, S. Y., 1995. Hemolymph oxygen content, oxyhemocyanin, protein levels and ammonia excretion in the shrimp Penaeus monodon exposed to ambient nitrite. Journal of Comparative Physiology, 164B: 530-535

Chen, J. C., Chen, C. T. and Cheng, S. Y., 1994. Nitrogen excretion and changes of hemocyanin, protein and free amino acid levels in the hemolymph of Penaeus monodon exposed to different concentrations of ambient ammonia-N at different salinity levels. Marine Ecology Progress Series, 110: 85-94

Chien, Y. H., Pan, C. H. and Hunter, B., 2003. The resistance to physical stresses by Penaeus monodon juveniles fed diets supplemented with astaxanthin. Aquaculture, 216(1):177-191.

D'Aniello, A. and Giuditta, A., 1980. Presence of D-alanine in crustacean muscle and hepatopancreas. Comparative Biochemistry and Physiology, 66B: 319-322.

Devereaux, M.K., 1986. Intermediary metabolism in the juvenile lobster Homarus americanus (crustacean, protein requirement, aquaculture, ammonia excretion, hepatopancreas). Ph.D. Dissertation, University of California, pp. 242.

Doumas, B. T., Watson, W. A., and Biggs, H. G. (1971). Albumin standards and the measurement of serum albumin with bromcresol green. Clinica chimica acta, 31(1), 87-96.

Gibson, R. and Barker, P. L., 1979. The decapod hepatopancreas. Journal of Oceanography and Marine Biology, 17:285-346. 
Gross, P. S., Bartlett, T. C., Browdy, C. L., Chapman, R. W. and War, G. W., 2001. Immune gene discovery by expressed sequence tag analysis of hemocytes and hepatopancreas in the Pacific white shrimp, Litopenaeus vannamei, and the Atlantic white shrimp, L. setiferus. Developmental and Comparative Immunology, 25: 565-577

Hennig, O., Itami, T., Maeda, M., Kondo, M., Natsukari, Y. and Takahashi, Y., 1998. Analyses of hemolymph immunoparameters in kuruma shrimp infected with penaeid rod-shaped DNA virus. Fish Pathology, 33(4): 389-393.

Lakra, W. S., Reddy, A. K. and Harikrishna, V., 2014. Technology for commercial farming of Pacific white shrimp Litopenaeus vannamei in inland saline soils using ground saline water. CIFE Technical Bulletin-1, 2014: pp.1-28.

Le Moulac, G., Klein, B., Sellos, D. and Van Wormhoudt, A., 1996. Adaptation of trypsin, chymotrypsin and a-amylase to casein level and protein source in Penaeus vannamei (Crustacea Decapoda). Journal of Experimental Marine Biology and Ecology.

Le Moullac, G. and Van Wormhoudt, A., 1994. Adaptation of digestive enzymes to dietary protein, carbohydrate and fibre levels and influence of protein and carbohydrate quality in Penaeus vannamei larvae (Crustacea, Decapoda). Aquatic living resources, 7(3): 203-210.

Li, E., Chen, L., Zeng, C., Yu, N., Xiong, Z., Chen, X. and Qin, J. G., 2008. Comparison of digestive and antioxidant enzymes activities, haemolymph oxyhemocyanin contents and hepatopancreas histology of white shrimp, Litopenaeus vannamei, at various salinities. Aquaculture, 274(1): 80-86.

Liu, W., Zhi, B. and Zhan, P., 2013. Effects of Salinity on Haematological
Biochemistry and Structure of Liver Tissue in Young Chum Salmon (Oncorhychus keta). North Pacific Anadromous Fish Commision, 9: 217221.

Mandal, A. K., Sharma, R. C., Singh, G. and Dagar, J. C., 2010. Computerized database on salt affected soils in India. Technical Bulletin: CSSRI/Kamal/1/1010. pp. 1-28

Meunpol, O., Hall, M. R. and Kapoor, V., 1998. Partial characterization and distribution of kynurenine aminotransferase activity in the black tiger prawn (Penaeus monodon). Comparative Biochemistry and Physiology, 120B: 139-143

Misra, H. P. and Frodovich, I., 1972. The role of superoxide anion in the autooxidation of epinephrine and a simple assay for SOD. Journal of Biological Chemistry, 247: 3179

Mohankumar, K. and Ramasamy, P., 2006. Activities of membrane bound phosphatases, transaminases and mitochondrial enzymes in white spot syndrome virus infected tissues of Fenneropenaeus indicus. Virus research, 118(1): 130-135

Perazzolo, L. M., Gargioni, R., Ogliari, P. and Barracco, M. A., 2002. Evaluation of some hemato-immunological parameters in the shrimp Farfantepenaeus paulensis submitted to environmental and physiological stress. Aquaculture, 214(1): 19-33.

Rahman, S. U., Jain, A. K., Reddy, A. K., Kumar, G. and Raju, K. D., 2005. Ionic manipulation of inland saline groundwater for enhancing survival and growth of Penaeus monodon (Fabricius). Aquaculture Research, 36 (12): 1149- 1156

Renhold, J. G., 1953, Manual determination of serum total protein, albumin and globulin fraction by Biuret method. In: 
Standard method of clinical chemistry (ed. Reiner, M.). Acadmic Press, New York, pp 88.

Riche, M., 2007. Analysis of refractometry for determining total plasma protein in hybrid striped bass (Morone chrysops $\times$ $M$. saxatilis) at various salinities. Aquaculture, 264: 279-284

Rick, W. and Stegbauer, H.P., 1974. $\alpha-$ Amylase measurement of reducing groups. In: Methods of enzymatic analysis (2): 885-889.-3175.

Roy, L. A., Davis, D. A., Nguyen, T. N. and Saoud, I. P., 2009. Supplementation of Chelated Magnesium to Diets of the Pacific White Shrimp, Litopenaeus vannamei, reared in Low- salinity Waters of West Alabama. Journal of the World Aquaculture Society, 40(2): 248254.

Roy, L. and A. Davis. 2010. Supplementation of potassium, magnesium, and sodium chloride in practical diets for the pacific white shrimp Litopenaeus vannamei, reared in low salinity waters. Reviews in Aquaculture, 2(4): 46-60

Roy, L., 2006. Physiological and nutritional requirements for the culture of the Pacific white shrimp, Litopenaeus vannamei, in low salinity waters. Reviews in Aquaculture, 2(4): 61-78

Rudneva, I. I. and Kovyrshina, T. B., 2011. Comparative study of electrophoretic characteristic characteristics of serum albumin of round goby Neogobius melanostomus from Black Sea and Azov Sea. International Journal of Advanced Biological and Biomedical Research, 1(1): 131-136.

Sa nchez, A., Pascual, C., Sa nchez, A., Vargas-Albores, F., Le Moullac, G. and Rosas, C., 2001. Hemolymph metabolic variables and immune response in Litopenaeus setiferus adult males: The effect of acclimation. Aquaculture 198, $13-28$

Sies, H., Stahl, W. and Sundquist, A. R., 1992. Antioxidant functions of vitamins. In: Annals of the New York Academy of Sciences, 669(1): 7-20.

Takahara, S., Hamilton, H. B., Neel, J. V., Kobara, T. Y., Ogura, Y. and Nishimura, E. $\quad$ T., 1960. Hypocatalasemia: a new genetic carrier state. Journal of Clinical Investigation, 39(4): 610.

Van Wormhoudt, A., 1973. Variation des protéases, des amylases et des protéines solubles au cours du développement larvaire chezPalaemon serratus. Marine Biology, 19(3): 245-248.

Woolen, F. J., 1964. U.S. Patent No. 3,125,281. Washington, DC: U.S. Patent and Trademark Office.

Wooten i. D. P. 1964. Microanalysis. In: Medical Biochemistry $4^{\text {th }}$ edn (ed. Churchill, J. and Churchill, A.) London, pp. 101-107

\section{How to cite this article:}

Iffat Jahan, Showkat Ahmad Dar, Garima Anand, Shashank Singh, A.K. Reddy, Arun Sudhagar, V. Harikrishna and Srivastava, P.P. 2017. Enzymatic Alterations in Litopenaeus vannamei (Boone, 1931) Juveniles Exposed to Different Levels of Dietary Potassium and Magnesium Reared in Inland Saline Water. Int.J.Curr.Microbiol.App.Sci. 6(11): 773-780. doi: https://doi.org/10.20546/ijcmas.2017.611.091 